\title{
The Universal Declaration of Human Rights of 1948 in the history of cosmopolitanism
}

\author{
Samuel Moyn
}

In the course of 1948, debates around the Universal Declaration of Human Rights, to be ratified by the United Nations General Assembly in December of that year, gained some traction in European public consciousness ${ }^{1} .1$ This essay originated as a lecture in both the "Around 1948" and "International Women's Human Rights" Sawyer Seminars at the University of Chicago on November 29, 2011, and the text sticks close to the original format. I am grateful to Christine Stansell and Linda M.G. Zerilli for the invitation and to the members of the audiences at the lecture as well as the seminars that followed. I would also like to thank Leela Gandhi and Deborah Nelson who improved the text, and Todd Shepard and others at a session of the Johns Hopkins University Political and Moral Thought Seminar who forced significant changes.

\footnotetext{
${ }^{1}$ This essay originated as a lecture in both the "Around 1948" and "International Women's Human Rights" Sawyer Seminars at the University of Chicago on November 29, 2011, and the text sticks close to the original format. I am grateful to Christine Stansell and Linda M.G. Zerilli for the invitation and to the members of the audiences at the lecture as well as the seminars that followed. I would also like to thank Leela Gandhi and Deborah Nelson who improved the text, and Todd Shepard and others at a session of the Johns Hopkins University Political and Moral Thought Seminar who forced significant changes.
} 
When revising an essay for its inclusion in The Discovery of the Mind (one of the most celebrated books of the mid-century humanities across the Atlantic world), Snell added the following remarkable passage: "Euripides, in his Medea, is the first to portray a human being who excites pity by the mere fact of being a human being in torment. [A]s a barbarian she has no rights, but as a human being she has. This same Medea is also the first person in literature whose thinking and feeling are described in purely human terms. ... No sooner does man declare his independence of the gods, than he acclaims the authority of the free human spirit and the inviolability of human rights" ${ }^{\text {. }}$

To say that the Medea is a parable about human rights, simply because it dramatizes the pitiable fate of a foreigner under the sway of local prejudice, is a rather remarkable assertion of course. Yet Snell's interpretation of this moment in the classical past remains exemplary - and not only in its now commonplace linkage of suffering, pity, individuality, and rights. For more basically, it starts out with a model of singular cosmopolitan breakthrough, which continues to pervade the contemporary historiography of human rights.

Since Snell's time, to be sure, few have made anything of Euripides. More often, they have credited the Stoics for the invention of humanity thanks to that philosophical movement's

\footnotetext{
${ }^{2}$ Bruno Snell, The Discovery of the Mind: The Greek Origins of European Thought, trans. T.G. Rosenmeyer (Cambridge, Mass., 1953), 250. The essay was added to the second German edition of the book, which is the basis for the English translation cited here. The introduction of the present essay summarizes another piece of mine, which then goes more deeply into alternative cosmopolitanisms, while this one applies those lessons to 1948 as a significant moment in the history of these cosmopolitanisms. See Samuel Moyn, "Plural Cosmopolitanisms and the Origins of Human Rights," in Costas Douzinas, ed., The Meanings of Human Rights (Cambridge, forthcoming). See also earlier my The Last Utopia: Human Rights in History (Cambridge, Mass., 2010).
} 
discovery, in the tracks of Diogenes the Cynic, of the "cosmopolis" or community of all human beings. The model is one of insight beyond the boundaries of family, tribe, or nation; and after the Stoics, medieval spirituality, Scholastic natural law, the Renaissance, William Shakespeare, and (of course) Immanuel Kant have also earned admiration for this selfsame breakthrough ${ }^{3}$. In the end, however else most accounts of the emergence of human rights may differ, 1948 is the most uplifting moment - though the point of such narratives of breakthrough is that there is a last leg in a kind of moral relay race for cosmopolitanism's heirs to run today ${ }^{4}$.

This approach makes the history of modern human rights generally, and the 1948 achievement of the Universal Declaration of Human Rights in particular, valuable to study and for a crucial reason. It casts them as the near conclusion and culmination of the epoch-making emergence of cosmopolitanism, defined - as Snell did in his reading of Euripides - as the universalistic inclusion of all humanity in the set of morally relevant subjects of political concern and action. Yet conceptualizing the aspiration to human unity as a singular achievement turns out to be deeply implausible; and if so, then shifting how to conceive of universalism in history entirely alters the questions to pose to and about the Universal Declaration. It might even suggest that the barrage of recent attention to human rights in 1948 is misplaced (including in this dossier, illuminatingly but also perhaps symptomatically).

${ }^{3}$ Lynn Hunt, Inventing Human Rights: A History (New York, 2007) famously offers the same scheme of suffering, pity, individuals, and rights but locates the breakthrough in the Enlightenment; see also now Kate Tunstall, ed., SelfEvident Truths?: Human Rights and the Enlightenment (New York, 2012).

${ }^{4}$ Mary Ann Glendon, A World Made New: Eleanor Roosevelt and the Universal Declaration of Human Rights (New York, 2001); see also, e.g., Elizabeth Borgwardt, A New Deal for the World: America's Vision for Human Rights (Cambridge, Mass., 2007), or more recently Akira Iriye et al., eds., The Human Rights Revolution: An International History (New York, 2012). 
On reflection, the model of singular breakthrough shared by Snell and contemporary historiography is deeply unpersuasive, in part because there have been so many different candidates for when exactly the cosmopolitan insight occurred. What if cosmopolitanism was easy to achieve historically? Is the genuine difficulty that localist and otherwise parochial moralities have predominated, given that universalist moral visions litter the annals, the victims not solely of narcissistic particularisms but also of their own bitter contention? While skepticism of various claims to transcend moral parochialism - Christianity's over Judaism, for instance, or communism's over capitalism - has proved simple, the most provocative consequence of this skepticism has never been drawn in the widespread debate among scholars and in public about where human rights came from. It is that cosmopolitanism is best studied not in the singular but in the plural. As Sheldon Pollock has arrestingly contended: "There has been not just one cosmopolitanism in history but several"5.

Pollock's general proposition seems simple, but it has a number of decisive ramifications, besides forcing the rejection of the notion of singular breakthrough. If it is correct, Michel Foucault was wrong that humanity is an invention of recent date; far more important was the variety of claims on its basis, and perhaps from the beginning of human culture. Similarly, Carl Schmitt was mistaken that those who have always invoked humanity have always lied, concealing particular interests, for the condition of cosmopolitan aspiration turns out to be its articulation in some

\footnotetext{
${ }^{5}$ Sheldon Pollock, The Languages of the Gods in the World of Men: Sanskrit, Culture, and Power in Premodern India (Berkeley, 2006), 280. See also Carol A. Breckinridge et al., eds., Cosmopolitanism (Raleigh, 2002), in which Pollock's chapter provides a brief overview of his theses. Compare Lydia Liu's essay in this dossier for a model of understanding human rights in the 1940s that fruitfully remains oriented around universalism and particularism.
} 
particular version. Put differently, cosmopolitanism is not just a cheat or smokescreen but what makes the specific program that it harbors ideologically appealing (something that Karl Marx, in opposing bourgeois universalism with another kind, well understood).

Arguably, then, cosmopolitanism not only comes in the plural, but articulations of it have teemed all along, indeed struggled with one another vigorously. And indeed they have done so in the heart of the tradition of "the West" - a point for which Pollock's insight needs to be adapted since he developed it through a comparison of different antique civilizations. Any story of cosmopolitanism anywhere, if Pollock is right, needs to be as much about the conflict of ideologies as much as about the breakthrough to one; and if this insight is helpful for understanding history long ago, it is even more decisive a tool for conceptualizing it very recently. As late as the Cold War already on in 1948, which was a battle to the death of rival cosmopolitanisms, "humanity" was crucial, but only in different articulations aiming to supplement or to displace one another. 1948 is, in short, not the turning point in the path of a singular cosmopolitanism but the scene of struggle between different kinds - a struggle in which the appeal to and of human rights was actually very minor.

That there was not just one cosmopolitanism in 1948 but several - and that the Universal Declaration's lonely version may have been marginal to their contention - is not the usual framework in thinking about the document, which is usually chronicled and celebrated simply for its emergence. This exclusionary focus on the making and content of the Universal Declaration has taught us a great deal, no doubt, but solely about diplomatic origins; it is, overwhelmingly, a story of a small number of elites, working in the interstices of a fledgling and problematic international 
organization $^{6}$. Beyond those severe limits it has had several quite unfortunate drawbacks. It has overly made the story of diplomatic penmanship overly dramatic (indeed melodramatic), though when it came to the document's content, in spite of a few modest squabbles, nearly everyone agreed about it, including both sides of what would become the Cold War rift. But most basically, the historiography failed to ask whether anyone cared about the Universal Declaration at the time - and if not why not.

The truth is that, in real time, the nation-state exiting patriotic war won as a political form, and nationalism won as a political ideology, though this claim needs to be specified from several different angles. Above all, I will contend that the national welfarist consensus is the far more significant feature of 1948 than the Universal Declaration - and indeed that "human rights," to the extent they were significant at all, became one more and rather infrequent synonym for this consensus. This conclusion is then possible to test by looking to those few Western Europeans who were in the 1940s the only forces anywhere who simultaneously gave refuge to supranational human rights, seeking a supplementary vessel for cosmopolitanism beyond their nation-states reconstituted around a welfarist ideal. Even that commitment to human rights quickly merged into another term for shelter under America's Cold War wing - though it bore unexpected fruit much later in contemporary European human rights culture. Both the American and Soviet side were to fight the Cold War in cosmopolitan terms or as ultimately humanistic struggle with (where necessary) humanistic violence, and no international human rights movement emerged immediately. All of these cosmopolitan solutions, from

\footnotetext{
${ }^{6}$ See, e.g., Johannes Morsink, The Universal Declaration of Human Rights: Origins, Drafting, and Intent (Philadelphia, 2000) or more recently William Schabas, ed., The Universal Declaration of Human Rights: The Travaux Préparatoires, 3 vols. (Cambridge, 2013).
} 
nationalism to Cold War supranationalism, would have to enter crisis for a global ethic of human rights in our contemporary sense to achieve the salience it now has?

I realize some may bridle at my suggestion that nationhood and nationalism are cosmopolitan; yet they have been a much more immediately obvious, practically transformative, and likely effective version of cosmopolitanism in world history - certainly more so than international human rights politics so far. Nationalism not only sought to reach individual protection through collective emancipation, but it also started from the premise that collective subjects - larger than the individual though smaller than all humankind - equally deserved the power to determine their own fate. The rights of man had been the fruit of the French Revolution, but what they meant for Europe in the nineteenth century was primarily the birth of nationalist movements. Historians have attempted to look for equivalents to Amnesty International in the era, starting with the antislavery international; it is not so much that they are wrong as that their preconceptions make them unable to see that the primary legacy of the rights of man was the mobilizational search for the revolutionary nation-state that "human rights" now seem principally about containing and subordinating to higher law. One of the major reasons the reference to universality and nature waned so significantly in the nineteenth century was the general conclusion that the invocation of man and nature led or even amounted to the local task of constructing citizenship spaces through particular struggles for collective freedom and then for the meaning of citizenship.

\footnotetext{
${ }^{7}$ Moyn, The Last Utopia, chap. 4. The battle over which side in the Cold War could claim that its violence served humanity is already presaged and analyzed in Maurice Merleau-Ponty, Humanisme et terreur, essai sur le problème communiste (Paris, 1947), translated by John O'Neill as Humanism and Terror: An Essay on the Communist Problem (Boston, 1969).
} 
Appeal to transcendent rights may well have stimulated the project of revolutionary founding or refounding, starting with John Locke and his settler heirs in what became the United States and running through modern transatlantic and indeed global history. But when different sides of local politics appealed to them as a basis for revising citizenship, their uselessness became plain. For it soon became clear that what mattered more was not the prepolitical appeal the contending sides in politics could make to nature to support its interpretation of citizenship, but rather who won the political struggle and the mandate to pass laws in the service of that interpretation ${ }^{8}$. Hannah Arendt was probably mistaken, in On Revolution, in her belief that that natural rights were a useless distraction from the project of founding modern nation-states; but she was undoubtedly correct that our nineteenthcentury ancestors found natural rights unhelpful in adjudicating their contending visions of citizenship within those political communities. As she accurately put it in her celebrated analysis in The Origins of Totalitarianism, the rights of man were "treated as a sort of stepchild by nineteenth-century political thought and ... no liberal or radical party in the twentieth century ... saw fit to include them in its program.... If the laws of their country did not live up to the demands of the Rights of Man, they were expected to change them, by legislation ... or through revolutionary action".

For all that rights were shunned on the basis of nineteenth century learning, it is nonetheless true that cosmopolitan

\footnotetext{
${ }^{8}$ For a classic exposition, see Marcel Gauchet, "Les droits de l'homme ne sont pas une politique," Le Débat 3 (July-August 1980), rpt. in Gauchet, La condition politique (Paris, 2005).

${ }^{9}$ Hannah Arendt, The Origins of Totalitarianism, 3rd ed. (New York, 1968), 293. For some relevant citations showing Arendt long connected rights and religion, and disavowed them both for the sake of secular politics, see my "Hannah Arendt on the Secular," New German Critique 105 (Fall 2008): 71-96.
} 
aspirations remained important through nationalism, understood as the liberation of peoples usually thought to entail individual protection. The so-called "springtime of nations" in 1848 is emblematic here. The universalistic premise of nationalism that all peoples should determine their own fate seems to have been the most appealing cosmopolitanism throughout modern history, and that is perhaps because while collective emancipation could afford individual protection, the reverse was not obviously true. Movements like the civil liberties movements that emerged at the turn of the twentieth century or the interwar vogue of proclaiming rights in the constitutions of new nation-states are definitely worth noting, as long as it is clear that these did not aim at or give rise to significant movements to place rights above nation-state.

In diplomatic relations, in fact, the origins of the United Nations, one of whose very minor byproducts was the drafting of the Universal Declaration, conceded the sovereignty of nations far more fundamentally than the prior experiment at international organization of the interwar years. What is remarkable is how little the version of cosmopolitanism known as international human rights, notably compared with the Christian and imperial cosmopolitanisms of prior centuries which so easily authorized intervention and expansion in the international system, was allowed to qualify national sovereignty in the 1940s. The UN Charter makes this fact utterly clear, permitting the use of force only for the sake of security or peace in its text (and for the sake of humanity or justice only in our own day and through interpretative departure from its terms). The dismaying truth may be that no sooner had human rights become an available diplomatic moral cosmopolitanism, than the international system became one based more thoroughly on impregnable sovereignty than before. As Mark Mazower has emphasized, internationalism has a long history, and its contending versions mattered as much in 1948 as at any other 
time. But not only is internationalism (itself with plural forms in contention) merely one form of cosmopolitanism, knitting the nations it presupposes together. For the supplement it provided diplomatically to the victory of the nation-state in the 1940s was actually then - and may remain - relatively minor. Put another way, Giuseppe Mazzini's nationalist legacy by far predominated in 1948 over his internationalist complement ${ }^{10}$. But since I have emphasized this diplomatic point so much in a recent book that covers how human rights became eligible through the UN's wartime formation to be declared in 1948 at all, I would much rather focus on other matters ${ }^{11}$.

The fact is that it still remains to ask why citizens followed their politicians - ignoring the minor bit of lip service the latter gave in the 1940 s to international human rights - in opting massively and wholeheartedly for some defensible version of national welfarism. Citizens did so enthusiastically because their nation-states were making unprecedented promises that were simply much more exciting than any attempt to guarantee human rights above the nation. Welfarism reached its height, and therefore across the North Atlantic the state empowered in wartime reached the height of its peacetime functionality in history so far, precisely beginning in the 1940s when various commitments to welfarism were shouldered across the zone of industrial democracy, including across lands that became communist. The salient question was not whether welfarism, but which kind, and how much, resolutely within the national framework. As Gunnar Myrdal pithily

\footnotetext{
${ }^{10}$ Mark Mazower, Governing the World: The History of an Idea (New York, 2012), which casts Mazzini as godfather of contemporary liberal internationalism, alongside Karl Marx's competing internationalism, which was likewise still prominent in 1948.

${ }^{11}$ Moyn, The Last Utopia, chap. 2.
} 
explained, looking back at this extraordinary consensus, "the welfare state is nationalistic"12.

The Universal Declaration's cosmopolitanism needs to be placed back in this atmosphere, where the general conclusion from World War II was that economic disaster underlay military conflict, and guaranteeing freedom from want would prove the key to securing freedom from fear. Probably most people who heard of the Universal Declaration and its idea of human rights understood it as what it announces itself to be, a "common standard of achievement for all peoples and nations," in which social and economic rights figured fully ${ }^{13}$. Put differently, it was a template for national welfarism. For most of those few who noticed the document at all, it was a kind of checklist for all nations to consult, in particular in making welfarist protection the highest promise of collective politics. But to say so is also to acknowledge that such promises were more readily available already locally, and were in fact the object of old and new struggles by 1948 .

There are three important implications of this fact for assessing the true relevance (or more accurately, comparative unimportance) of the Universal Declaration in 1948. For one thing, the main substance of many of the oldest of those struggles had long since marginalized individual rights as the proper language for achieving welfare. Briefly put, the world seemed to have learned by the 1940s that you certainly could talk about welfarism outside the paradigm of individual rights, and you might need to do so.

\footnotetext{
${ }^{12}$ Gunnar Myrdal, Beyond the Welfare State: Economic Planning in the Welfare States and Its Internationalist Implications (London, 1960), 117. Consider what would happen if the approach of James T. Sparrow, Warfare State: World War II Americans and the Age of Big Government (New York, 2011) were generalized to the entirety of the North Atlantic industrial zone.

${ }^{13}$ Universal Declaration of Human Rights, G.A. Res. 217A(III), U.N. Doc A/810 at 71 (1948).
} 
Obviously anyone who read Karl Marx (and there were a lot more fitting that description in the 1940s than now) suspected as much. But we have perhaps forgotten that the fiftyyear history of the fight for welfare before 1948 where capitalism remained the horizon of politics - as in the Anglo-American sphere - was very often a struggle against natural rights, in philosophy and in courts, where they had been primarily deployed to protect the inviolability of contractual freedom and private property. By the postwar moment, in fact, the debate around which sort of welfare to have was never or hardly ever intellectually organized around a cleavage between those supporting and those rejecting rights in the abstract. It is now popular to conceive of modern history as a forum of expanding rights claims or "rights cascades." The difficulty with this scheme is that it cannot see that most progressive political positions, not least the campaign for welfare, endorsed the language of rights rarely and strategically. Philosophically, liberalism itself hardly flirted with the ideological priority of rights between the 1790 s and the 1970 s.

Second and inversely, therefore, national welfarism had a massive number of other idioms in which to proceed to frame its agenda, and in general succeeded under those alternative banners. Whether in the name of the common good or social solidarity or the general welfare, social protection most often got however far it did from place to place outside the paradigm of rights, especially individual rights. There are obviously exceptions to this statement, such as Franklin Delano Roosevelt's evanescent proposal of a Second Bill of Rights in 1944 or even the International Labour Organization's Philadelphia declaration the same year ${ }^{14}$. But

\footnotetext{
${ }^{14}$ See Cass R. Sunstein, The Second Bill of Rights: FDR's Unfinished Revolution and Why We Need It More Than Ever (New York, 2006); Alain Supiot, The Spirit of Philadelphia: Social Justice versus the Total Market (New York, 2012).
} 
one may not overstate the prominence, or persistence, of these framings either. It would be a serious mistake, then, to imply that the progress of welfarism between the 1930s and the 1950s in any way depended on the ideological ascendancy of rights talk - even the introduction of social rights.

And third and most important, the Universal Declaration by the late date of its passage simply offered no new tools to or for various national struggles to promote welfarism in some form. Because historians have focused on the emergence of the Universal Declaration they have not even looked for evidence that that process made a practical difference in debates around social citizenship and so far as I know there is no such evidence. If anything, it was rearguard because it preserved a memory of fuller wartime consensus around welfare than obtained just a few years later when national politics had already been reframed around the still familiar sides arguing for more or less welfare. It was ignored, most probably, because its belated fiction of consensus clashed so vividly with the realities of domestic infighting. The stark fact is that the Universal Declaration has proved far more useful to ourselves than to those living in its time. No one has asked why, though it is the right quandary to solve both to understand our ancestors and ourselves.

What of the Holocaust? It is an essential concern because of the now deeply ingrained assumption that the entire aftermath of the World War II, and the Universal Declaration not least, just must have been a response to the Jewish genocide. But contrary to a generally shared opinion, a cosmopolitan morality based on our memory of what has become the emblematic state atrocity did not emerge in the 1940s, and at the risk of offending current pieties one might suggest that there were good reasons and not simply bad faith that determined this result. 
The Universal Declaration does indeed refer to the "disregard and contempt for human rights [that] have resulted in barbarous acts which have outraged the conscience of mankind." This meant that every nation had its horrors, since the Nazis did many terrible things. The most famous outrages on humanity of the 1940s were Leningrad and Lidice not Belzec or Treblinka. In any event, for practically no one and for few Jews was the Holocaust, to the extent its enormity was understood at all, the rationale for suprastate law. From the pillars of postwar legalization like the Nuremberg principles, the genocide convention, and the Geneva Conventions, the Universal Declaration stands essentially apart, otherwise unconcerned with wartime violence, shunning international law, and reposing hopes for welfare in national self-assertion. The much more popular internationalist response to the Holocaust as such probably occurred in Eastern Europe as antifascism; and for Jews outside the now depopulated "bloodlands," allegiances were won essentially by nationalism at home in the form of integration or abroad in the form of often novel Zionist commitments.

In their cosmopolitanism centered on national welfarism (or outright socialism), however, Jews were fully in conformity with their times ${ }^{15}$. In United Nations records it seems that no one - the one possible exception is the likely author of that line, French Jew

\footnotetext{
${ }^{15}$ This development was once obvious even to those critical of it. Consider Isaac Deutscher: "The world has compelled the Jew to embrace the nation-state and to make of it his pride and his hope just at a time when there is little or no hope left in it. You cannot blame the Jews for this; you must blame the world. ... [Jews] did not benefit from the advantages of the nation-state in those centuries when it was a medium of mankind's advance and a great revolutionary and unifying factor in history. ... I hope, therefore, that together with other nations, the Jews will ultimately become aware - or regain the awareness - of the inadequacy of the nation-state." Isaac Deutscher, "The Non-Jewish Jew," in The Non-Jewish Jew and Other Essays, ed. Tamara Deutscher (London, 1968), 41, and Ariella Azoulay's essay in this dossier.
} 
René Cassin - had what is now known as the Holocaust of European Jewry in mind in the preambular reference to barbarous acts ${ }^{16}$. At least, no diplomats from anywhere mentioned the Holocaust during the yearlong debate around the Universal Declaration. There are a number of not very creditable reasons for this surprising finding. But one creditable reason - a reason that many Jews at the time actually shared - is that it seemed important to put the past behind or to dwell on it, unlike us, as motivation for a welfarist or otherwise solidaristic alternative to the horrors of aggressive war. (To a remarkable extent, in spite of our memory of them as atrocity tribunals, the Nuremberg trials were also primarily about what would happen when bad actors ruined interstate coexistence, given the overwhelming priority given to the stigmatization of aggressive war in the proceedings, especially by American and Soviet politicians and prosecutors.) ${ }^{17}$

Because of the national welfarist consensus that human rights were one way to denominate in wartime, and by the time of the Universal Declaration one way to recall as that consensus declined, humanity in the 1940s seems to have rejected much interest in the past in order to insist emphatically on creating a common future. Criminalizing atrocity had not yet become humanity's fondest hope. If the Universal Declaration was a response to experience, it was essentially one of depression and war, not really one of atrocity and genocide, and for the sake of a rapid pivot to building the future. This is the best reason that our ancestors so quickly chose to skirt the difficult knowledge about who exactly had suffered in the past, distant but also recent, and who had suffered more or most.

\footnotetext{
${ }^{16}$ See now Marco Duranti, "The Holocaust, the Legacy of 1789 and the Birth of International Human Rights Law: Revisiting the Foundation Myth," Journal of Genocide Research 14, no. 2 (2012): 159-186.

${ }^{17}$ Francine Hirsch, "The Soviets at Nuremberg: International Law, Propaganda, and the Making of the Postwar Order," The American Historical Review 113, no. 3 (June 2008), 701-730.
} 
That the 1940s were the great age of the nation-state, and not human rights, is most graphically reinforced by developments in the world of imperial politics. Actually those living under imperial rule had even deeper reasons to skirt international human rights in favor of other cosmopolitanisms. Above all, they had learned through mimicry as well as through the prior history of international politics that collective selfdetermination was the formal universalism to choose to advocate, especially if individual protection was at stake. Anticolonialism, thus, had long since signed on to the rights of man movements of the French Revolution's aftermath, and much new research suggests that it was Mazzini, long before the catalytic effect of twentieth-century politicians like V.I. Lenin and Woodrow Wilson, who lit the fire of anticolonial nationalism around the world, with enthusiastic responses stimulated by the catalyst of festering grievance, and undergirded by local and often collectivist ethical sources ${ }^{18}$. But there was a far more short-term and unpalatable set of reasons why anticolonialism in the 1940s, kicking off the process of globalizing national welfarism under the auspices of state sovereignty, did not find international human rights compelling.

The chief one, obviously, was that during World War II the first promise the Allies seemed to make in their vision for the globe was one of emancipated peoples, before the Allies took that promise back. The Atlantic Charter of 1941 affirmed "respect [for] the right of all peoples to choose the form of government under which they will live; [with] sovereign rights and self government restored to those who have been forcibly deprived of them." But

\footnotetext{
${ }^{18}$ See e.g. C.A. Bayly and Eugene Biagini, eds., Giuseppe Mazzini and the Globalisation of Democratic Nationalism, 1830-1920 (Oxford, 2008).
} 
Winston Churchill assumed it was obvious this promise applied to Adolf Hitler's empire, not empire in general, and certainly not his empire. Roosevelt came around to this view by the time of his death - precisely the years during which human rights made what little headway they did in the North Atlantic world as a possible synonym for welfarism.

According to historians of places across the world, the Atlantic Charter's promise of self-determination incited a huge amount of enthusiasm. Amazingly, the historiography of the Universal Declaration of Human Rights, simply assuming its monumental impact, assumes it globally, but there is little evidence of it. The real politics of the moment were, however, registered by those who have since often been thought to be confused votaries of cultural relativism: American anthropologists. It is just as plausible to view them as insisting on the prior, and perhaps better, form of cosmopolitanism the Allies had once offered, since they closed their famous 1947 statement condemning human rights with the following words: "The world-wide acclaim accorded the Atlantic Charter, before its restricted applicability was announced, is evidence of the fact that freedom is understood and sought after by peoples having the most diverse cultures"19. Far from being full-blown cultural relativists, the anthropologists understood themselves to be speaking for a cosmopolitanism that competed with human rights - and was displaced by them ${ }^{20}$. In geopolitical terms the replacement of self-determination by human rights, as an

\footnotetext{
${ }^{19}$ Executive Board, American Anthropological Association, "Statement on Human Rights,” American Anthropologist, n.s., 49, no. 4 (October-December 1947), 539-543.

${ }^{20}$ This crucial point is frequently missed by anthropologists following the history of their discipline; compare Mark Goodale, Surrendering to Utopia: An Anthropology of Human Rights (Stanford, 2009). See also Liu's discussion of the statement in this dossier.
} 
instance of the competitive rivalry of cosmopolitanisms, remains one of the most fateful turning points in modern history.

Admittedly, the fact that the text of the Universal Declaration did not include collective self-determination may have been a minor failure, since the Universal Declaration, while abstaining from condemning empire, was not really intended to interfere with the nation-state. And the situation was eventually corrected as selfdetermination became the first human right in legal covenants brought about by decolonization decades later. But this crucial series of events does help explain why decolonization came to proceed based not on global human rights ideas but the collectivist sovereignty of the nation-state, since taken to the ends of the earth ${ }^{21}$. The 1940s founding of India and Pakistan (and Israel) set the terms for what followed, in the tradition of revolutionary nationalism, and far more people paid far more attention to these events, especially if they found themselves under the reconsolidating empires of the era.

A zealous criticism of teleological histories of human rights should not, of course, mean uncritically accepting teleological histories of nationalism and the nation-state. In fact, a significant movement in contemporary scholarship contends that in 1945 or even 1948 the triumph of the nation-state as the normative political form

\footnotetext{
${ }^{21}$ See Moyn, The Last Utopia, chap. 3, and Moyn, "Imperialism, SelfDetermination, and the Rise of Human Rights," in Iriye et al., eds., The Human Rights Revolution. To me, this story matters more now, since it mattered much more then, than the fact one can find a few in diplomatic fora such as the UN Commission for Human Rights who imagined a compatibility of the Universal Declaration's promise with galloping nationalism. Anyway, in Mazzini's tradition nationalism had generally implied protection of individual prerogatives from the first. Compare Liu's essay in this dossier as well as my "Giuseppe Mazzini in (and Beyond) the History of Human Rights," in Miia Halme-Tuomisaari and Pamela Slotte, eds., Human Rights and Other Histories (forthcoming).
} 
remained years away. Setting itself the task of recovering lost visions whose percolation under empire postponed outright ideological victory of nationalism, this movement surely not wrong to emphasize the plurality of possibilities the achieved or "invented" form of decolonization destroyed ${ }^{22}$. In my own work I have emphasized that the victory of the nation-state after 1945 still allowed for highly creative subaltern internationalisms whose agenda from the Bandung Conference in the 1950s to the New International Economic Order in the 1970 s contrasts starkly with the reign of human rights since. But restoring the contingency of nationalist victory even as late as World War II, like insisting on the plural internationalisms this victory still allowed, cannot interfere with two related basic points. One is that the 1940s were much closer to the "telos" of the era of globalized nationalism than to that of the era of international human rights. The other is that there is substantial evidence of nationalist victory already in the 1940s, so much so that what needs to be explained is not just the exciting contingency of the era but also that it was already beginning to be overdetermined that nationalist solidarity was soon to succeed so comprehensively.

Faisal Devji's The Impossible Indian: Gandhi and the Temptations of Violence (Cambridge, Mass., 2012), esp. epilogue, emphasizes that Mohandas Gandhi was no nationalist, while also underlining his skepticism towards human rights. There is a parallel literature in Jewish studies emphasizing roads not taken and lost political alternatives that a statist Zionism ruled out.

\footnotetext{
${ }^{22}$ For the most accomplished form of this skepticism, see Todd Shepard, The Invention of Decolonization: The Algerian War and the Remaking of France (Ithaca, 2006); from a longer-range perspective, see Jane Burbank and Frederick Cooper, Empires in World History: Power and the Politics of Difference (Princeton, 2010) as well as Cooper's essay in this dossier and Manu Goswami, "Imaginary Futures and Colonial Internationalisms," American Historical Review 117, no. 5 (December 2012): 1461.
} 
Consider three texts concerning rights from between 1945 and 1949. The first, invoking the American Revolution's natural rights, immediately adds: "In a broader sense, this now means: All the peoples on the earth are equal from birth, all the peoples have a right to live, to be happy and free." The second claims the "natural right of the ... people to be masters of their own fate, like all other nations, in their own sovereign State." The last begins "We the people," like the American Constitution, but the rest of the preamble specifies that sovereignty now means socialism, and as a matter of fact social and economic justice is immediately listed - even before political justice. These are from the Declarations of Independence of Vietnam and Israel, respectively, and the Indian Constitution. (None mention "human rights," let alone the Universal Declaration, and for anyone curious about how the Holocaust figured in rights declarations of the era, it is the Israeli Declaration, not the Universal Declaration, that alone acknowledges the Holocaust very directly, albeit with different consequences.)

In many places, including all three of these, revolutionary nationalism required a fight along the way. And as before, in movements for citizenship fully compatible with violence when push came to shove (Mazzini, after all, had also written terrorist manuals) human rights in the contemporary sense were put off or left aside because the nation-state surged not as an affirmation of particularity alone but as the highly idealistic vehicle of cosmopolitan humanity enjoying a modular nationalism with no provision for superordinate constraint. The 750,000,000 people the United Nations left colonized voted with their feet for a cosmopolitanism that implied their collective emancipation with more assurance and with more practical meaning than "international human rights" did. 
Actually the fact is that human rights, most especially in the Universal Declaration, were primarily though not exclusively the language of the imperial powers, and these Western European lands were the only ones where human rights survived the ideological cacophony of the moment after World War II, compared to everywhere else in the world. (And even their publicists there did not normally believe that human rights portended interference in still widespread colonial holdings.)

Of course, in Europe, national welfarism prevailed more than anywhere else. Even there (or especially there), the real debate in domestic politics was about how to create social freedom in the state. But revealingly, some early "federalist" plans for Europeanization did insist on the importance of human rights, but from a potentially unexpected quarter. Begun around the same time as the Universal Declaration, the European Convention's negotiation extended later; and this fact meant that the fiction of ideological consensus about basic values prized in wartime could no longer be maintained even at the stage of formulating norms. The February 1947 communist takeover in Czechoslovakia made the threat elsewhere seem so vivid, and the protection of private property surged in importance. The internment and trial of Cardinal József Mindszenty, the Primate of Hungary, in 1948-1949, and related abuses of Christians in

Eastern Europe like the house arrest of Czech Cardinal Josef Beran occurred so quickly after the Universal Declaration as to help define its bearing, and in fact these were the main international human rights abuses understood in those terms in the era ${ }^{23}$. West Europeans responded by making religious freedom the keystone

${ }^{23}$ See Andrew Martin, "Human Rights and World Affairs," Year Book of World Affairs 5 (1951): 44-80. 
of the new document. It had already been the core of the Universal Declaration for the Protestants and even Catholics most interested in its framing; now it received even more emphasis ${ }^{24}$.

Welfarist values may not have been so anathema to West Europeans, in part because they were more compatible with both religion and conservatism than in the United States where the Universal Declaration was soon denounced as "pink paper." But in the origins of the Cold War the priorities within human rights certainly shifted and the European Convention ended up dropping social and economic rights. At the time, European socialists primarily regarded the European Convention project as a threat, because they understood that their conservative rivals were trying to internationalize the struggle over the extent of welfarism, tarring socialism with the brush of communist expropriation ${ }^{25}$.

If it was after World War I, in the face of unprecedented dangers, that what Charles Maier famously called bourgeois Western Europe was first "recast," it was after World War II that it was re-recast, with the difference that new economic foundations and a transatlantic security space were linked to the ascendancy of the sort of Christian political parties in power that had never existed with the same prominence, or accepted either liberal democracy or supranational governance ${ }^{26}$. Only in a Western Europe in the era of conservative and Christian Democratic hegemony, human

\footnotetext{
${ }^{24}$ See my "From Communist to Muslim: Religious Freedom in European Human Rights Law," South Atlantic Quarterly 113, 1 (Winter 2014): 63-86.

${ }^{25}$ Marco Duranti, Human Rights and Conservative Politics in Postwar Europe (New York, forthcoming).

${ }^{26}$ Charles S. Maier, Recasting Bourgeois Europe: Stabilization in France, Germany, and Italy in the Decade after World War I (Princeton, 1975); Maier, "The Two Postwar Eras and the Conditions for Stability in Twentieth-Century Western Europe,” American Historical Review 86, 2 (March 1981): 327-52; Wolfram Kaiser, Christian Democracy and the Origins of the European Union (Cambridge, 2007).
} 
rights survived as an idealistic slogan from wartime, and were legalized on paper with supranational scope. In a comparative sense, this move went far beyond the fate of international human rights everywhere else at the time, which was that they were simply ignored altogether. But the European Court of Human Rights it set up began as a moribund institution that surprisingly took flight, along with international human rights generally, after the Cold War's end. In an absolute sense, therefore, the legalization of supranational norms in the 1940s was close to meaningless, even if it laid the foundation for the unexpected explosion of European human rights in our time. The spiritual and later industrial Europeanization of the immediate postwar era barely conflicted with and, according to one historian, may even have "rescued" the European nation-state ${ }^{27}$. But Western Europe was most definitely the only place where the goal of qualifying or superseding the sovereignty of the nation-state in the name of human rights got anywhere. Looking back, actually, it is not clear if this occurred too much in the 1940s, or not enough, given a much later version of unified Europe's financial and political crisis today. Whichever the case, the evidence is not promising for seeing the idea of international human rights as a successful European cosmopolitanism at the time to worthy of uncritical celebration in ours.

Because there were other cosmopolitanisms than we have, there could also be other ones than we realize. At least until later events made nationalism but also socialism disfavored and perhaps for understandable reasons, international human rights did

${ }^{27}$ Charles S. Maier, Recasting Bourgeois Europe: Stabilization in France, Germany, and Italy in the Decade after World War I (Princeton, 1975); Maier, "The Two Postwar Eras and the Conditions for Stability in Twentieth-Century Western Europe," American Historical Review 86, 2 (March 1981): 327-52; Wolfram Kaiser, Christian Democracy and the Origins of the European Union (Cambridge, 2007). 
not fare well in the clash of cosmopolitanisms. If so, what now seems crucial is not any of the many alleged breakthroughs to "humanity" in world history or in 1948. Instead it is what happened since then for human rights to seem like the only viable kind of cosmopolitanism there is now. And so returning to 1948 primarily forces recognition that other cosmopolitanisms appealed then instead - ones we may well have lost, even as years later with the rise of Holocaust memory, the tragedies of decolonization, and the collapse of socialism a commitment to human rights that humanity bypassed in the 1940s became our own credo.

I myself think that most prior cosmopolitanisms were discarded for good cause, but also that as a movement and an ethic international human rights gained their contemporary authority, over the past forty years alone, mainly because more prominent, substantial, and transformative movements lost prestige. As a result, it is not surprising that the ascendancy of human rights not in the 1940s but in our time has made them far less politically useful than the romantic treatments they have attracted in the historical literature might have led one to hope. Most of all, our strenuous attempt to build a myth of what the 1940s clearly did not contribute, a global idealism of human rights, has made us skirt the real significance of the period, not simply for observers at the time but most especially from a present-day perspective.

After all, the prestige of human rights and the salience of human rights movements in our time have coincided with the destruction since the 1970s of what welfarists set out to dream in the 1940s. It is an eerie and disturbing coincidence that no one has explained. In the earlier era, neoliberal intellectuals at Mont Pelerin and the invisible hands of businessmen's advocacy were only beginning their networked campaign to band together and destroy 
the welfarist consensus ${ }^{28}$. In the age of rights, they succeeded to a striking degree. In the earlier moment, the conjuncture was not yet imaginable in which, three decades later, what solidarity World War II had forged, even in places where welfarism had been defined against socialism, rotted in domestic settings, even as international politics saw the explosion in prominence of international human rights norms begin. The relationship between the withering of local, costly solidarity and the afflatus of distant, cheap solidarity is the main puzzle in accounting for the contemporary prominence of human rights, including the Universal Declaration's belated prestige, and it is crucial now to solve it.

I doubt it would have made much difference if recent public and scholarly analysts had chosen to emphasize the national welfarist version of cosmopolitanism in the 1940s. But it now seems unfortunate that even as their politicians were dealing welfare states some of their final indignities, observers after the Cold War followed an enthusiastic public discourse in making international human rights not welfare states what World War II was fought to achieve. As for the bigger portion of the world that bypassed human rights in the 1940s, the period since the 1970 s is one in which, for good and for ill, the postcolonial sovereignty so strenuously achieved at least in formal terms and as the object of perhaps the most genuinely planetary idealism in world history so far has been qualified - and in some places seriously so. In the meantime, where our ancestors in the 1940s shouldered the task of achieving summum bonum of the good society through the state, Westerners eventually learned the lessons of the Holocaust and

${ }^{28}$ Kim Phillips-Fein, Invisible Hands: The Making of the Conservative Movement from the New Deal to Reagan (New York, 2009); Angus Burgin, The Great Persuasion: Reinventing Free Markets since the Depression (Cambridge, Mass., 2012); see also Daniel T. Rodgers, Age of Fracture (Cambridge, Mass., 2011). 
organize their moral consciousness around the summum malum of atrocity in war and the body in pain, especially when these seem to follow from someone else's misrule. Cruelty became the worst thing we (or they) can do, not solidarity the best thing we can achieve. In Europe, Christian conservative hegemony that alone favored human rights in the 1940s eventually lost its hold, and in new circumstances human rights became at first a widespread transatlantic then global lexicon.

With respect to Bruno Snell or his followers in crafting a deep past for human rights, no classical or modern moment of breakthrough insight is helpful in understanding any of these rather recent events, though they are the ones that retrieved the Universal Declaration from its marginality to be the global touchstone of the present day. I do think those events are mostly depressing, but my goal is not to be deflationary, except about the Universal Declaration, and only to make room for the inflation of other things. Nostalgia for the lost welfarist ideal, of course, is not productive in itself, especially given its own shortcomings - many related to the very bordered and other exclusions that made its solidarity plausible to its denizens ${ }^{29}$. Neither could one sensibly oppose some sort of transnational solidarity. But the 1940s did not offer any version of it that was practically effective then or ideologically plausible now, and in fact a convincing transnational politics is something still broadly lacking - beyond the enterprises the 1940s gave us of conflict resolution in which the great powers matter most and a very particular and contestable version of regulated global capitalism along with efforts at humanitarian palliation in the face more of exigent crisis than structural deprivation ${ }^{30}$.

${ }^{29}$ Compare Tony R. Judt, Ill Fares the Land (New York, 2010) with Samuel Moyn, "Studying the Fault Lines," Dissent 58, 2 (Spring 2011): 101-5.

${ }^{30}$ Consider Jean L. Cohen, Globalization and Sovereignty: Rethinking Legality, Legitimacy, and Constitutionalism (Cambridge, 2012) for its critique of human rights millennialism but also for the absence in it of any transnational 
If national welfarism left a great deal to be desired, and there is no historical precedent for global welfarism, these facts do not redound to the benefit of an international human rights agenda that has generally sought nor provided either national or global welfare. Rather, international human rights politics originated in the 1970s by sticking, and perhaps defensibly, to a minimal package of norms like free speech and integrity of the body. The problem is that this occurred as the more thoroughgoing dreams for national welfare of the 1940s were dropped, and no agenda of global welfare has followed in compensation. The recent pretense by historians but also public figures that the 1940s gave us a more robust global vision, in public rhetoric and in an affirmative historiography, has gone along with the world historical processes that have led us not simply to spurn, but also to forget, the valuable features of nationalism, most notably a welfarist ideal that by current standards got so far.

Since their rise as a prestigious moral and political option just a few decades ago, and especially since the Cold War's end, international human rights movements and politics, in spite of some estimable contributions, have arrogated the patrimony of humanity, as if they were its fulfillment. In a sense, Bruno Snell had the last laugh. It is not so much that it is historically mistaken to accept the temptation to read the past - from the Greeks to the French Revolution and beyond - as a fund of precedents for our current political aspirations; my objection goes to the limited nature of the aspirations themselves. The past is not merely authority for the minimalist improvements the international human rights movement typically seeks and sometimes wins $^{31}$. As in the biblical story of Jacob, it is always possible to resist an apparently inexorable lineage for the sake of a different future.

agenda for politics other than Security Council reform and "low-intensity" constitutionalization beyond the state.

${ }^{31}$ See my "Do Human Rights Treaties Make Enough of a Difference?” in Conor Gearty and Costas Douzinas, eds., Cambridge Companion to Human Rights Law (Cambridge, 2012). 
